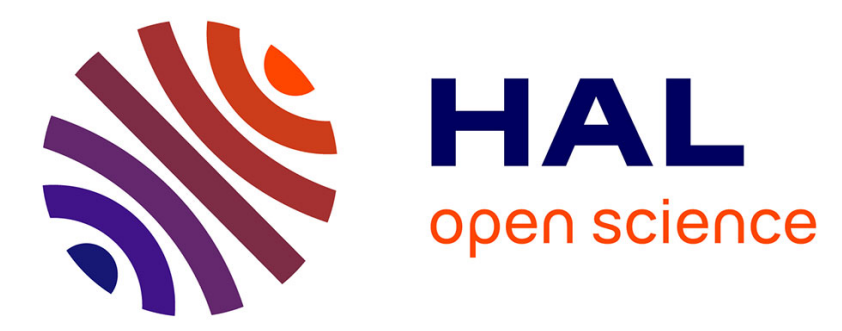

\title{
Endogenous Berber Forest Management and the Functional Shaping of Rural Forests in Southern Morocco : Implications for Shared Forest Management Options
}

Didier Genin, Romain Simenel

\section{To cite this version:}

Didier Genin, Romain Simenel. Endogenous Berber Forest Management and the Functional Shaping of Rural Forests in Southern Morocco: Implications for Shared Forest Management Options. Human Ecology, 2011, 39 (3), pp.257-269. 10.1007/s10745-011-9390-2 . hal-02100603

\section{HAL Id: hal-02100603 \\ https://hal-amu.archives-ouvertes.fr/hal-02100603}

Submitted on 16 Apr 2019

HAL is a multi-disciplinary open access archive for the deposit and dissemination of scientific research documents, whether they are published or not. The documents may come from teaching and research institutions in France or abroad, or from public or private research centers.
L'archive ouverte pluridisciplinaire HAL, est destinée au dépôt et à la diffusion de documents scientifiques de niveau recherche, publiés ou non, émanant des établissements d'enseignement et de recherche français ou étrangers, des laboratoires publics ou privés. 


\title{
Endogenous Berber Forest Management and the Functional Shaping of Rural Forests in Southern Morocco: Implications for Shared Forest Management Options
}

\author{
Didier Genin • Romain Simenel
}

(C) Springer Science+Business Media, LLC 2011

\begin{abstract}
On the basis of two case studies in rural Morocco, one in a mountainous area of the Central High Atlas and the other in the argan tree area of the southwest Atlantic coast, we show how local Berber populations have actively shaped their forest areas through endogenous management systems at different scales: 1) at the individual tree level by differential cutting or trimming which lead to specific conformations of the tree, 2) at the tree stand level, by determining the type, structure and level of resources, and 3) at the landscape level in which complementary patches of forest areas with particular functions are consciously organized within the overall territory. These practices are strongly linked with the overall socioeconomic organization of the local communities, and mix individual with common rights of access and uses. Forests are viewed as part of the domestic sphere of local livelihoods. Hence, they typically constitute what we refer to as rural or domestic forests since they integrate production and conservation with social, political and spiritual dimensions. These features are of importance for considering foresterlocal community relationships, and for developing alternative forest management policies.
\end{abstract}

Keywords Agdal practices - Forest shaping - Rural forest . High Atlas · Argan forest $\cdot$ Morocco

\footnotetext{
D. Genin $(\bowtie) \cdot$ R. Simenel

Laboratoire Population, Environnement, Développement, IRD, Université de Provence,

Centre Saint Charles, case 10,

13331 Marseille cedex 3, France

e-mail: didier.genin@univ-provence.fr

R. Simenel

e-mail: romain.simenel@ird.fr
}

\section{Introduction}

Forests and rural livelihoods have a long historical interconnection. Forests resources provide food, fuelwood, and materials for construction, handicrafts and medicinal and ritual purposes. In Southern Morocco, forests grow under semi-arid conditions and form more or less extensive areas of dry forests that are intensively exploited by rural societies and that are usually undergoing degradation (Bencherifa and Johnson 1991; Gauquelin et al. 1999). Commonly advanced possible causes of degradation cite either mismanagement and over-exploitation of forest resources by local populations, generally associated with a high rate of demographic expansion and a low level of rural development, or unilateral state appropriation of forests (following the management approach of the French colonial period (Aubert 2010)) resulting in alienation from forest resources of local societies who formerly practiced sound endogenous management systems. Some authors have cast doubt on this "generalized degradation" paradigm (Davis 2005), and Simenel (2011) has recently shown that endemic argan tree (Argania spinosa) regeneration in Southern Morocco has been facilitated by multi-faceted coordinated actions between soil adjustments, exclosures, shoot protection, and overall landscape organization and uses.

Forests still constitute a critical element of farming systems and contribute to the structure of landscapes as well as the definition of rural territories. Berber communities have developed extensive local knowledge and skills related to forest use and conservation. In particular the management system known as agdal encompasses specific areas, resources and access rules formulated by local populations in order to manage their territory (Auclair and Alifriqui 2007), although use of this system is in decline 
nowadays due to socioeconomic changes that have attected rural societies. At first sight, this secular endogenous forest management system appears to fulfil all the institutional principles considered important for sustainable resource management (Ostrom 1990; Armitage 2005): well-defined groups, resources and boundaries; participation of all actors in defining the rules; a graduated scale of sanctions for rule-breakers; mechanisms for conflict resolution; and a self-monitoring system whereby resource users are accountable for their own actions. The agdal system is holistic and can be considered the result of a long trajectory of man-nature interactions through which Berber societies have developed pragmatic knowledge and practices in order to adapt to a particular constraining and changing environment. It is thus fully in accord with the indigenous knowledge or traditional ecological knowledge framework (Blaikie et al. 1997; Peloquin and Berkes 2009), and the quadriptyc proposed by Berkes (2008) of knowledge-practice-institution-worldview to understand complexity in traditional natural resource management systems. Understanding traditional ecological knowledge hence constitutes one of the mainstays of the domestic forest paradigm proposed by Michon et al. (2007) who argue that the domestic forest is "a forest for living, a forest that integrates production and conservation, with social, political, and spiritual dimensions" (p.17).

However, the potential of this endogenous forest management system is seldom recognized by the authorities in charge of forest management and its ecological and social impacts are poorly documented, if at all (Hammi et al. 2010). In particular, little is known about how local people perceive their forest areas in terms of improving their livelihood and ensuring resource availability. As Bloch (1995) argued, perception of landscape is in fact a driving motivation with regard to the commitment of farmers to pursue their own course in ecosystems management.

On the basis of two contrasting situations (a high altitude area in the High Atlas and an argan tree area), we first aim to show how Berber rural societies have taken control of their forest resources at different scales (individual trees, tree stands, landscapes), and hence have shaped their forest landscapes into diversified patches in order to satisfy material, social, cultural and long-term needs. However, since their vision of forest management often conflicts with that of the forestry authorities, our second aim is to identify the main points of conflict and to explore ways to reconcile them.

\section{Study Areas and Methods}

Berber communities in Morocco occupy an extensive area mainly stretching from the mountains of the Middle and
High Atlas to the southern parts of Ant1-Atlas chain and pre-Saharan zone. For the purposes of two interdisciplinary research programs related to traditional natural resources management and relationships between local forest management and public policies, ${ }^{1}$ we focused on two contrasting sites located in the Berber area: one in the Central High Atlas (the Ait Bouguemez valley), the other near the south-western Atlantic coast (Imint'lit).

The Ait Bouguemez valley is located in the province of Azilal at altitudes ranging from 1,800 to $2,200 \mathrm{~m}$, and is surrounded by high mountain ranges reaching altitudes of 3,700 m (Azourki, Waougoulzat). It contains approximately 30 villages (douars) stretching along the bottom of the valley, which has a Mediterranean highland-type climate, with a semi-arid variant in the bottom of the valley and subhumid on the most well watered mountainsides (Couvreur 1968; Lecestre-Rollier 1986). The extreme temperatures range from -15 to $+45^{\circ} \mathrm{C}$. The annual rainfall varies between 500 and $750 \mathrm{~mm}$, and precipitation is irregularly distributed in time and space, but is more abundant during autumn and spring. Annual (wheat, barley, alfalfa, potatoes) and tree (apple, walnut) crops are cultivated in the bottom of the valley, irrigated by channels (seguias) diverting water from the rivers, along some plots of dry cultivation (bour) in the bottom of the valley and lowers parts of the slopes. The village boundary is arranged perpendicularly to the axis of the mountains. Communal wooded areas supplying firewood, leaf fodder and supporting grazing flocks cover the mid- and upper parts of the slopes. The lower parts of the wooded areas close to the villages are often managed as agdal, while the high forest areas (outside the agdal) are open to free forest utilization. The asylvatic areas at high altitude constitute collective rangelands for flocks of sheep and goats. Some parts of these pastoral areas are also managed as agdal (Genin et al. 2011). The local economy is dominated by agro-pastoral activities. Forests and shrublands cover the north and south sides up to 2,400-2,700 m, and show contrasted density and degradation levels. The wooded vegetation is arranged in levels according to the altitudinal gradient, exposition and management system, with three species of Juniper: (Juniperus phoenicea, J. oxycedrus, J. thurifera), and holm Oak (Quercus ilex)

We studied 11 villages located in the upper part of the valley (altitude above 1,900 $\mathrm{m}$ ), which are administratively part of the Commune of Tabant (Azilal Province). All these villages use traditional natural resource management

\footnotetext{
${ }^{1}$ The agdal Program (2003-2007) "Les agdals du Haut Atlas marocain: biodiversité et gestion communautaire de l'accès aux ressources forestières et pastorales», supported by the French Institute for Biodiversity (IFB); and POPULAR Program (2007-2010) "Politiques publiques et gestion paysanne de l'arbre et de la forêt: alliance durable ou dialogue de dupes?", supported by the French National Research Agency (ANR-06-PADD-014).
} 
methods and have various areas managed in agdal. An earlier interdisciplinary survey explored the socioeconomic characteristics of these villages (Genin 2008), and mapped the different agdals (pastoral and forested) as well as their broad functioning (Hammi et al. 2010).

Our second fieldwork site was the rural Commune of Imint'lit, belonging to Essaouira Province. It is situated in the northern part of the argan tree range, which extends over 800,000 hectares in south-western Morocco, about $15 \mathrm{~km}$ from the Atlantic coast at an altitude of between 100 and $800 \mathrm{~m}$, and has a Mediterranean semi-arid climate, annual precipitation of about $300 \mathrm{~mm}$, and mean monthly temperatures between 12 and $26^{\circ} \mathrm{C}$. The local economy is mainly based on agriculture (cereal crops, fruit growing: argan and olive trees, and smallstock rearing). Forests cover about $38 \%$ of the total Commune area, with two main tree species: the argan (Argania spinosa) and thuya (Tetraclinis articulata) in the upper parts. The argan tree, emblematic of the region, is an endemic species of the Sapotacea family whose fruit provides high quality oil used for cosmetic and culinary purposes, and with a market that has developed very strongly internationally during the last decade. It is also heavily browsed by goats, which are able to climb up it. Finally, it provides hardwood for fuel. Landscapes are strongly influenced by the woody component dominated by the argan tree. It occurs everywhere: among the crops at the bottom of the valley where individual trees are well developed but at low density in order to allow cereal cultivation under the canopy; on the slopes, at higher density but with a more fragmented growth pattern; at the top, mixed with thuya. Different individual and collective management modes are found locally in private or public areas: privately owned wooded crop areas, agdals (public areas, but with individual family rights, see below), ourtis (privately-owned areas dedicated to fruit production), and mouchaas (public areas managed by the forestry administration, and used as pastoral commons by local populations). This has resulted in a highly diversified wooded landscape.

We first conducted semi-structured interviews in order to detail forest management practices following the methodological approach of Olivier de Sardan (2000). These interviews were carried out with Naibs (community representatives in charge of the functioning of irrigated (water management) and collective lands (agdals)), stakeholders and, whenever possible, guardians of agdals or known key-informants. We also used information from earlier surveys concerning agro-pastoral systems in the High Atlas case study (Genin et al. 2011; Genin, 2008), and from Simenel's (2010) extensive anthropological research on Man-Nature relationships in the argan forest area. Questions addressed topics such as the precise description of the different wooded areas found in the village territory, followed by a GPS delimitation, linked access rights and use rules, perceptions on ecological states, types of practices involved and frequency, detailed actions on harvesting and cutting practices. Information presented here is based on more than 100 interviews conducted between 2004 and 2009. In particular, the interviews constitute the main basis for sampling ecological and tree characteristics of woody areas according to their management characteristics.

In the High Atlas case study, 27 sectors were identified in relation to 1) appropriation and management status (agdal and outside agdal), 2) dominant tree species (holm oak, Spanish juniper, mixed species of holm oak, and the three species of juniper), 3) main uses (foliage fodder and firewood collection, building timber, other), and 4) particulars of forest management (compartments within the agdal areas, rotations of extraction pressure, etc.) or tree stand configuration (holm oak matorral, big individualized trees, etc.). Eighty-one plots (three plots per sector) of $400 \mathrm{~m}^{2}$ each were selected for dendrometric measurements (tree morphotype, height, number and diameter of stems, foliage volume, number of cutting traces, etc.), and ecological characteristics (exposure, slope, soil type, herbaceous cover, using the point interception line method described by Daget and Poissonet (1972), and total number of plant species per plot). Data from these plots were also used for specific analyses of characteristics of individual trees depending on their main uses (timber production, fodder foliage, firewood extraction).

In the argan forest case study, more than six months of fieldwork and a good command of the local Berber language enabled us to undertake the vernacular classification of the sectors' terminology based on the main uses and land ownerships, and to use it as a basis for sampling vegetation. Hence, four sector types were undertaken for dendometric and ecological measurements:

- Fields, privately-owned slightly wooded areas dedicated to argan fruit production and annual crops (mainly wheat and barley),

- Ourtis, privately-owned wooded areas found at the bottom of the northern slope, and dedicated primarily to argan fruit production

- Agdals, family-owned argan trees on public lands, but collectively managed for both argan oil production and grazing

- Mouchaas, public areas managed by the forestry administration and used as pastoral commons by local populations.

The same methodology of measurements as for the High Atlas case study was adopted within $39400 \mathrm{~m}^{2}$ plots in order to characterize trees and tree stand structures. A specific survey was undertaken by $\mathrm{Ba}$ (2009) in order to better characterize tree shapes. Careful observation allowed the characterization of 17 types, which were described, photo- 
graphed, and schematised using ARCGils y.3 sottware. Fieldwork mainly consisted in surveying the morphologytype of each tree found in 43 transects $20 \mathrm{~m}$ wide and of variable length (100-800 $\mathrm{m}$ depending on tree density and surface of homogeneous areas), and distributed over the four sector types. Quantitative data were processed using classic statistical analyses of means comparisons and variance analyses.

\section{Forest Agdals: An Original Endogenous Forest Management System}

Agdal is a generic Berber term designating areas where access rights and uses of natural resources are governed by a local institution-usually the village, inter-village or inter-tribal assembly — which fixes rules concerning periods and modalities of natural resource exploitation. Agdal management mainly concerns pastoral areas in the asylvatic upper parts of mountains (Ilahiane 1999; Mahdi 1999), but other specific territories, such as forests or sacred areas are also governed by agdal. It always involves a temporary respite from use with the aim of conserving or collecting resources for critical periods. Customary laws limit the boundaries of the agdal and fix its closing and opening dates. Agdal is an endogenous socio-spatial concept including a territory, resources, and rules and institutions regulating access and usages (Auclair and Alifriqui 2007). Our study is focused on forest agdals, which have been poorly, if at all, described.

In the High Atlas, forest agdals are located in the immediate vicinity of villages because their main function is to provide firewood for the communal mosque and fodder for livestock during winter if heavy snowfalls impede flock movements. While legally all forested areas belong to and are managed by the state authorities (Aubert et al. 2009), a village's forest territory is usually divided into a poorly regulated area where the major extractions of firewood and fodder occur and one or two agdal areas (between 20 and 200 ha). In both cases, they consist of open woodlands composed of pure or mixed tree stands of holm oak and junipers. The structure of tree stands will depend on the type of management (agdal or outside agdal), and on their functions, e.g., timber production, fodder production, etc. (Cordier and Genin 2008). At the village scale, forest agdals usually represent between $10 \%$ and $40 \%$ of total available forest territory, depending on village locality and population pressure.

Rules usually apply to the cutting of standing wood and foliage, while grazing is authorized year-round. During the period of cutting prohibition, people get supplies from outside agdal forest areas, which are thus subjected to higher harvest pressure. In the face of this situation, some villages have also established weaker rules concerning these outside agdal areas.

Tree foliage constitutes up to $20 \%$ of the annual diet of non-transhumant local small stock (Genin et al. 2011). Four types of rules apply to foliage collection, which may vary from village to village:

- 1. Periodicity of cutting. In the study villages this includes the periods of snow cover. Cutting may be authorized for all days or only during specific days of the week;

- 2. Quantities of harvest. Different quotas depending on the size of the family flock or fixed equal quotas for each family;

- 3. Division of agdal into sectors in order to allow rotational cutting. For example, in the village of Ighirine the large forest agdal is divided into six sectors and cutting authorized only alternately in two sectors each year;

- 4. Tree species to be cut. In some villages only holm oak is authorised for foliage cutting while cutting junipers is strictly forbidden because, according to informants, of a low regrowth capacity.

This corpus of rules can fluctuate depending on the size of available forest agdals and the weather, and also local perceptions of resource availability and village politics (Lecestre-Rollier 1986). Other extractable products, such as firewood, which is usually allowed only for the needs of the mosque, or timber for roof construction are subject to prior authorization by the village assembly. Custodians of the agdals are designated locally and rule breakers are fined or handed over to the local authorities.

In the argan tree area, there is specific legislation concerning argan forest management where users' rights are more recognised. The agdal system is widespread throughout the entire region and associated with other wooded lands submitted to diversified patterns of land tenure and uses. Agdals are located on public lands, but with specific rights allowed to local people. Two types of agdal are commonly found:

- 1. Sacred agdals are argan forests where the rights of use are exclusively reserved for the descendants of patron saints who are the custodians of these forests. These "sacred" areas are often given long periods of respite from use in order to regulate anthropic pressure and stimulate regeneration (Simenel 2011).

- 2. Seasonal agdals, with a compartmentalization of the area and usage rights allocated to clearly identified families, are aimed at limiting grazing during the argan fruiting period and managing fruit harvesting. Customary practice prohibits access to the forest by livestock usually from May to August. After fruit harvesting, carried out 
tamily by tamily, the torest agdal is opened up again tor all the village flocks. Hence, this customary institution complements and enhances the forestry law because it allows the spatio-temporal association of two types of rights: 1) collective grazing rights for all the members of the tribe or faction, and 2) family rights for fruit harvesting on well defined sections (Simenel et al. 2009). The agdal pattern of use thus dictates the rhythm for the agro-sylvo pastoral activities throughout the agricultural annual cycle.

Each village usually has a seasonal adgal, and each tribe a sacred agdal. The seasonal agdal is located on public lands, above the agricultural area. It is divided into plots on the basis of the crop plot distribution patterns. Entitled beneficiaries are usually from the same extended family, but sometimes rights are rented to non-family stakeholders.

\section{Rural Forests of Southern Morocco: Human-Induced Diversity}

Our purpose here is to show that the forests of the Southern Morocco have been deeply and consciously shaped by human action at different scales, from individual trees to landscape-level changes. This can be analysed in relation to the functions trees and forests contribute to the livelihoods of local populations.

\section{At Individual Tree Scale}

In these open forests one can find areas where tree species are managed for the exploitation of different resources. This is the case of Spanish juniper ( $J$. thurifera) in the High Atlas, which provides high quality timber due to the hardness of its wood and its capacity to reach diameters big enough for framework construction. Its foliage also constitutes relatively good forage for the winter diet of small stock. Local people reported that they clearly distinguished Spanish juniper individuals depending on the timber or fodder/firewood function they attributed to them. On the basis of a sample of 52 Spanish junipers found within the measurement plots, and presenting a basal diameter over $20 \mathrm{~cm}$, Cordier and Genin (2008) found marked differences in tree structure parameters, depending on their production function (lable 1). I'his leads to a diversity of tree conformation, and hence differentiated stands and ecosystems. This feature is also found in the Andalusian Dehesa where oak trees are intentionally pruned in order to favour mast production or timber (Joffre et al. 1999).

In Imint'lit, argan trees present a highly diversified tree structure according to their locality and customary functions. Ba (2009) proposed at least 17 types of individual tree architecture related to the main use to which they were dedicated (Fig. 1). For example, argan trees show typical umbrella or $\mathrm{Y}$ conformation in field areas, induced by differential pruning in order to reconcile fruit production and shade limitation for crops. Another typical tree structure found in field areas, which we refer to as "low wall," plays a role in the demarcation of land plots. In agdals, trees predominantly present structures that reconcile fruit production and accessibility for goat browsing. It is noteworthy that this man-induced diversity in argan tree conformation is highly valorised in the discourse of local people. In the local Tachelhit language, there are many words associated with the argan tree. The generic term argan designates the species overall. However, depending on size and morphology, different words are used, such as takcher (small spiny and shrubby argan), akcher (tall shrubby argan), targant (medium size argan tree up to $4 \mathrm{~m}$ tall), or argan (big tree above $5 \mathrm{~m}$ tall and usually isolated). The word amzddaday designates multi-stem tall argan trees, and amgeyl or akhzeyf identify argan trees providing extensive shade. Aguntif (lit. big pebble) refers to heavily browsed dwarf argan trees called 'green stones' by foresters. Argan trees without spines are called tamelhenet. The richness of the vocabulary testifies to an intimate relationship between local people and argan forest and provides evidence of the long-term domestication process of this tree species. It also reflects the perception of tree structure as an indicator of good or bad forest as well as an indicator of a tree's domestication and functional utility.

\section{At Tree Stand Scale}

For foresters this scale corresponds to a relatively homogenous surface unit where forest characteristics and manage-

Table 1 Comparison of individual tree conformation of Spanish Juniper (J. Thurifera) in relation to their main use (timber or fodder/firewood) (Ayt Bouguemez valley). Bold numbers indicate significant differences of means $(p<0,05)$

\begin{tabular}{lcccccc}
\hline & Height $(\mathrm{m})$ & $\begin{array}{l}\text { Tree cover } \\
\left(\mathrm{m}^{2} / \text { tree }\right)\end{array}$ & Basal area & $\begin{array}{l}\text { Crown area } \\
\left(\mathrm{m}^{3} / \text { tree }\right)\end{array}$ & $\begin{array}{l}\text { Number of cuts } \\
\text { per } \mathrm{m}^{2} \text { of cover }\end{array}$ & $\begin{array}{l}\text { Crown areas per } \mathrm{m}^{2} \\
\text { of } \mathrm{cover}^{3}\left(\mathrm{~m}^{3} / \mathrm{m}^{2}\right)\end{array}$ \\
\hline Framework tree $(n=34)$ & $\mathbf{5 . 4}$ & $\mathbf{4 6 . 2}$ & $\mathbf{0 . 5 4}$ & $\mathbf{1 0 5 . 1}$ & 0.34 & $\mathbf{2 . 1}$ \\
Fodder and firewood $(n=18)$ & $\mathbf{1 . 0}$ & $\mathbf{2 3 . 1}$ & $\mathbf{0 . 2 9}$ & $\mathbf{3 4 . 1}$ & 0.43 & $\mathbf{1 . 2}$ \\
Probability of student's test & $\mathbf{0 . 0 0 1}$ & $\mathbf{0 . 0 0 1}$ & $\mathbf{0 . 0 1 8}$ & $\mathbf{0 . 0 0 1}$ & 0.291 & $\mathbf{0 . 0 0 1}$ \\
\hline
\end{tabular}


tree physiognomy in relation to their localisation in the different wooded areas found at the village level (adapted from $\mathrm{Ba} 2009$ )

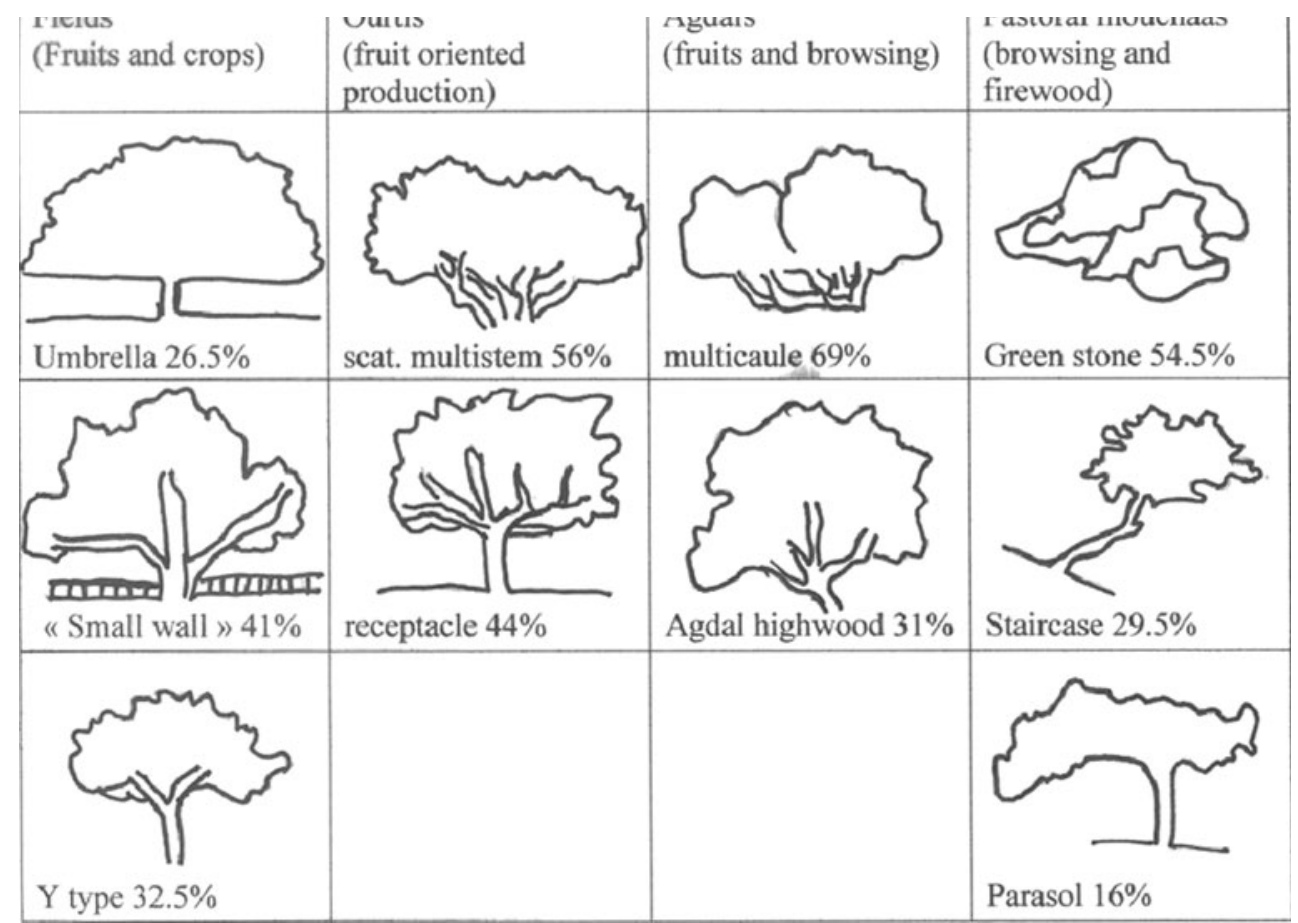

ment are undertaken on the basis of parameters such as timber cubage per hectare or tree cover and amount of forest resources available. It is also a pertinent scale for villagers who manage portions of their local forests.

In the High Atlas, a comparative study was conducted on 57 plots representative of holm oak dominated forests in order to assess the impact of agdal management on dendrometric characteristics of tree stands (35 agdal plots, 22 outside agdal plots) (Cordier 2007). Results showed that even although they present similar tree cover, agdal and non-agdal tree stands do not offer the same forest resources (Table 2). The food reserve function of agdal areas for livestock winter fodder is illustrated by almost twice the available amount of foliage $\left(2,995 \mathrm{~m}^{3} /\right.$ ha vs $\left.1,670 \mathrm{~m}^{3} / \mathrm{ha}\right)$. Outside agdal areas contain shorter trees easily available for firewood extraction, and a significantly higher proportion of matorral cover (holm oak $<1.5 \mathrm{~m}$ height) directly browsed by sheep and goats. Cordier (2007) presents a detailed analysis of the structure of these tree stands as well as their capacity for regeneration,
In the argan tree study area, structures of tree stands are highly diversified depending on the type of land tenure and management (Table 3). A low argan density field allows development of annual crops under and between canopies. Argan trees in fields are also pruned in order to favor main branches and hence size of argan nuts. They also have other functions such as land plot delimitation and in some cases ritual attributes. In ourtis and agdals, tree height is intermediate and is related to specific uses (forested rangelands associated with a main concern for the fruit crop). In mouchaa areas, high tree density is linked to low tree height as a result of intense browsing and wood collection.

Local people have also developed at least 12 types of fruit classification since trees are individually cropped depending on nut quality, and can indicate predominance of certain types in particular areas. For example, trees with nuts that are easily broken for extraction of the almond are frequently cropped first and rapidly treated for oil processing in order to benefit from high prices on the local market before peak production. Even though farmers claim not to

Table 2 Comparison of tree characteristics of holm oak and Spanish juniper stands subjected or not to agdal forest management (Aï Bouguemez valley). Bold numbers indicate significant differences of means $(p<0,05)$

\begin{tabular}{lcccccc}
$\begin{array}{l}\text { Total } \\
\text { cover }(\%)\end{array}$ & $\begin{array}{l}\text { Cover of Holm } \\
\text { oak matorral (\%) }\end{array}$ & $\begin{array}{l}\text { Cover of herbaceous } \\
\text { strata }(\%)\end{array}$ & $\begin{array}{l}\text { Holm oak basal } \\
\text { area }\left(\mathrm{m}^{2} / \mathrm{ha}\right)\end{array}$ & $\begin{array}{l}\text { Holm oak Crown } \\
\text { volume }\left(\mathrm{m}^{3} / \mathrm{ha}\right)\end{array}$ & $\begin{array}{l}\text { Spanish juniper } \\
\text { basal area }\left(\mathrm{m}^{3} / \mathrm{ha}\right)\end{array}$ & $\begin{array}{l}\text { Spanish juniper crown } \\
\text { volume }\left(\mathrm{m}^{3} / \mathrm{ha}\right)\end{array}$ \\
\hline 25 & $\mathbf{1 3}$ & 11 & $\mathbf{1 0 . 3}$ & $\mathbf{1 6 7 0}$ & 4.7 & 549 \\
26 & $\mathbf{3}$ & 13 & $\mathbf{1 4 . 7}$ & $\mathbf{2 9 9 5}$ & 3.8 & 779 \\
0.814 & $\mathbf{0 . 0 0 1}$ & 0.468 & $\mathbf{0 . 0 3 7}$ & $\mathbf{0 . 0 0 2}$ & 0.634 & 0.139 \\
\hline
\end{tabular}


argan tree stands depending on the type of forest management in Imint'lit (Province of Essaouira)

\begin{tabular}{lllll} 
& Fields $(n=9)$ & Ourtis $(n=9)$ & Agdals $(n=9)$ & Mouchaas $(n=12)$ \\
\hline Tree density/ha & $56 \pm 21$ & $127 \pm 89$ & $167 \pm 39$ & $170 \pm 52$ \\
Tree height $(\mathrm{m})$ & $6,1 \pm 1,7$ & $4,5 \pm 0.8$ & $4,3 \pm 1,9$ & $2,8 \pm 2,9$ \\
\hline
\end{tabular}

modify the natural distribution of these types, it would be interesting to analyse in more detail the selections they make and their domestication practices for individual tree selection in field and ourtis areas.

\section{At Landscape Level}

Our careful observation of wooded areas at the study sites revealed that they are compartmentalised into a complex mosaic of discrete zones each with its own physiognomy and history. For example, the village of Iqabaliun, in the
Bouguemez valley, presents at least six forest compartments (Fig. 2):

- on the south-facing slope, an agdal composed of red Juniper exclusively dedicated to pole extraction for roof building (I);

- on the north-facing slope where the main part of village forest is found, another agdal is divided into five compartments alternatively exploited in pairs for fodder foliage and firewood extraction in winter (II), the fifth compartment (III) is exclusively dedicated to firewood
Fig. 2 Mosaïc of diversified forested areas with differential functions in the village of Ibaqaliun (Central High Atlas, Morocco). Image: SPOT/ HOA-QUI/EYEDEA.

I: Agdal for exclusive pole extraction; II: Agdal: four compartments alternatively exploited for fodder foliage and firewood extraction when snow; III: fifth compartment of the agdal exclusively devoted to firewood for the mosque; IV: degraded outside agdal divided in two compartments with a rota system of use; V: outside agdal reserved for beam extraction; VI: outside agdal open for free extraction

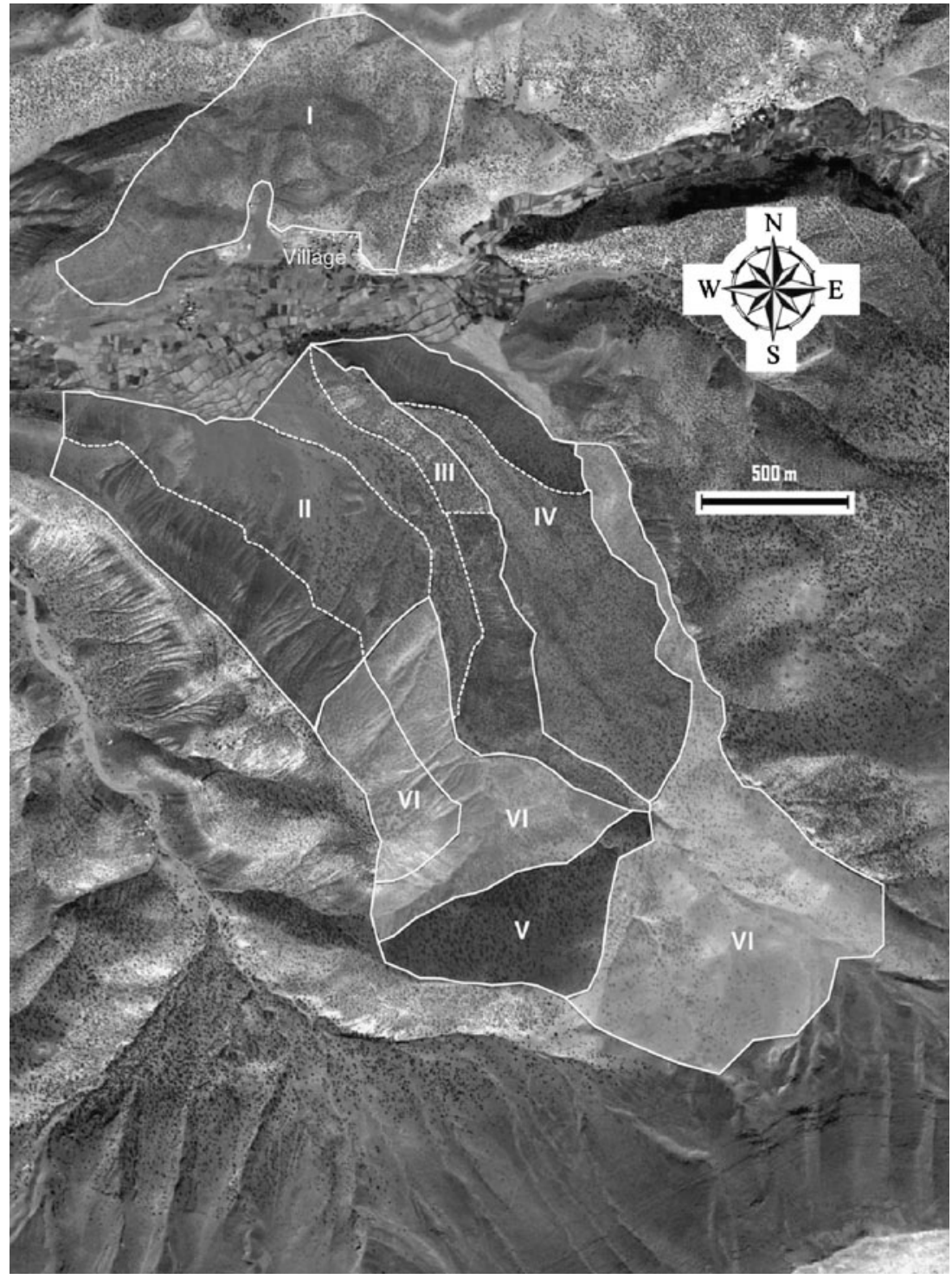


for the mosque (ablutions and heatıng); in the outside agdal zone, until recently wood and foliage extraction was free, but in the face of perceived degradation of forest resources, the village assembly decided ten years ago to divide the area into two and introduce a fouryear rotational system for its exploitation (IV); a specific remote outside agdal area is dedicated to sporadic use of Spanish juniper beams due to the presence of large old trees (V); the rest of the outside agdal area is open access usage (VI).

These forest formations, on the one hand, contribute to the ecosystemic diversity that is one component of the overall biodiversity (with genetic and species diversity), and on the other hand, constitute true integrated resource-spaces with complementary functions for rural livelihoods.

In the argan forest area, the landscape is also clearly compartmentalised into different types of argan stands corresponding to different levels of argan tree exploitation:

- on south-facing slopes, there is a large seasonal agdal where plots are extensions of private crop plots. Officially argan agdal is public land, but in each plot fruit is harvested collectively by the whole extended family and divided among members.

- on north-facing slopes in several privately-owned plots (ourti) enclosed by small stone walls argan trees are mixed with other fruit tree species, such as olives, almonds, prickly pears and henna trees. Argan nuts and firewood are collected individually by plot owners.

- $\quad$ at the bottom of the valley there are wooded crop plots and a banded mouchaa area primarily grazed by livestock during the closed period of the seasonal agdal, which also includes a pond for watering livestock.

- $\quad$ at the top is the public forest domain, used collectively as rangeland and for dead wood collection, and subject to forestry administration management.

\section{Farmers' and Foresters' Forest Management Systems: Towards Reconciliation?}

Traditionally, peasant farmers and foresters throughout the world have a long history of confrontation. This is also true in the Berber region, where conflicts between rural communities and forest administration authorities have sometimes turned violent (Lecestre-Rollier 1986). In our opinion, one of the main reasons for this lies in contrasting visions of what constitutes "good forest management" and ways to achieve it.

Forest authorities generally have two main objectives for forest management: resource conservation and timber production, associated with an almost exclusive scale of perception: the tree stand. In contrast, Berber tarmers perceive forests as a diversified resources source and an integrated element for the overall functioning of the local community in a context where natural environmental and socioeconomic risks are high. As we have shown their scales of perceptions of rural forest management range from individual trees to the overall landscape of the village territory.

Fundamental discrepancies between the goals of forest management authorities and local farmers can be highlighted: pluri-annual cycles of forest exploitation with occasional intensive yields for foresters, against a more diffuse year round pattern for peasant farmers. This leads to a more preconceived and rigid management approach by forest administration authorities, associated with strongly vertical relationships between the stakeholders. In contrast, the village assembly constitutes a form of forum of discussion for forest management decisions, where each family is represented, and where a certain flexibility of rules and uses can be collectively decided. This trait seems to be shared by a lot of traditional forest management systems found around the world (Uprety 2002).

Perceptions of biodiversity appear to differ. Foresters follow an academic conception and argue that each species and ecosystem must be protected in its own right. Hence, emphasis is also put on rare and endangered species for sound protection measures. Berber country people, by their own account, are also concerned by biodiversity but to a varying extent depending on the resources that are actually exploited. Genin et al. (2011) show that while peasant farmers explicitly explain their practices in pastoral agdals as maintaining high plant diversity (Alaoui et al. 2009), in forest agdals their main focus is on tree resources, and overall biodiversity is very rarely an explicit preoccupation. Nevertheless overall plant diversity was not higher in forest compared to non-forest agdals due to year-round livestock grazing (Genin et al. 2011). In their discourse, biodiversity is always linked to its utilitarian functions (whether material or immaterial), or a subtle perception of what might be called "biodiversity of function."

Ecological principles guiding forest management also seem to be perceived in different ways by the two groups. Foresters have a traditional approach inspired by the ecological succession theory of Clements (1936), where, put simply, there is a general trend to a "climax" state for vegetation and different forms of degradation. These principles have been largely integrated in foresters' vocabulary and management systems ("mature stand," degradation stages, long term respite from use, etc.). Human activities are usually viewed as a source of degradation, and forestry policies are first aimed at controlling forestland tenure and minimizing pressure on resources. Local knowledge is not formulated verbally to the same extent, but various authors have insisted that in a broad sense there is 
evidence for subtle and tlexible social and technical systems deployed to accommodate livelihood strategies and long-term perpetuation of resources (Leach et al. 1999; Parlee et al. 2006; Michon et al. 2007). In this sense, and without idealizing traditional practices, we may consider their approach closer to the new theories of opportunistic management at disequilibrium states (Behnke et al. 1993) and to the framework of "social-ecological systems" associated with "adaptive management" and resilience (Berkes et al. 2003; Dietz et al. 2003).

Two examples illustrate these different approaches. The first concerns holm oak matorral formations in the High Atlas, which are considered by technicians as highly degraded ecosystems, while for locals they constitute interesting resource-spaces easily valorized by direct browsing and firewood extraction, which does not seem to have an irreversible negative impact on regeneration dynamics (Cordier 2007).

The second concerns regeneration of the argan tree. Foresters undertake regeneration by complete felling of the overall tree stand, transplantation of new argan trees from nurseries, followed by a complete respite from use for 8 to 12 years (M'Hirit et al. 2002). As a consequence, all agrosylvo-pastoral activities remain prohibited for several years. These practices do not take into account any concern for local genetic diversity, since scientific knowledge and techniques are relatively weak in this domain. Smallholders have developed different practices which protect resprouts, natural seedlings, encouraging them to throw out suckers, and to conserve areas favourable to regeneration (hedges, ourtis, etc.). Hence, local regeneration management is performed tree by tree, sprout by sprout, and without considering the overall tree stand. It should also be emphasized that the concomitance of agricultural and forestry practices in the same area is favorable to argan regeneration, particularly germination, due to the presence of protective areas such as hedges, small walls, and terraces. This opportunistic management of natural regeneration leads 1) to favouring heterogeneity of tree age classes within tree stands, and 2) to a kind of genetic laying out (tracability) and choice of trees to be conserved. This is illustrated by the endogenous local terminology to identify filiations between tree generations, which mimics human family connections. Resprouts are thus considered as uterine nephews of neighbouring trees (ayao), while suckers are considered as sons (iwis). Locals usually argue the reality of these filiations on the basis of the strong similarity in fruit conformation. Regeneration and exploitation are conceived concomitantly.

As in the holm oak matorral case, peasant farmers in the argan forest do not perceive the overgrazed areas with dwarf argan as degraded or sacrificed areas, but as temporary useful resource-spaces with a clear potential to eventually return to more strongly torested states it the need arose tor the local population.

Officially, forest ownership and management in Morocco are exclusively the purview of the State following the Dahir (Law) of 1917 concerning forest protection and exploitation, which was issued under the French Protectorate and largely inspired by French law. Only a few rights are given to users: collecting on-the-ground dead wood, and light grazing (goats excluded), with the exception of the very particular argan forest area, where the legislation allows more extended rights to locals due to the importance of argan products (fruit for oil making, fodder foliage, wood) for farming systems to endure.

However, the Forestry administration has considerable difficulty implementing the legislation. In the Ait Bouguemez valley, for instance, as is common throughout remote areas of the High Atlas, a permanent forest guard was posted only in 1985 and forest areas under his control are very extensive. This is one of the reasons why traditional forest management has been perpetuated so widely until now. Foresters do not have the capacity to manage and control all forested lands, and are faced with a somewhat lack of knowledge concerning territorial and social aspects of local situations of which they are in charge. Hence, we are currently facing a double forest management system (local and "legal") made up mainly of dualism, but also of hybridization. This system is constantly being redefined, depending on the people involved, and changing mentalities and degrees of implementation of the laws. Aubert (2010) and Aubert et al. (2009) analyzed in depth the relationships between forestry administration and local institutions in the Moroccan mountains. They showed that several changes have occurred during the last 25 years; the reforestation of degraded areas by the forest administration - usually located on stands where conflicts occurred between villages for their control; some sporadic questionings of traditional rules and corruption among forestry officials; and in some villages, a certain loss of legitimacy of traditional institutions for forest exploitation regulation because some villagers prefer to deal directly with the forest guard in order to obtain large amounts of wood. As argued by Ilahiane (1999) in the case of pastoral agdals, "conflict and instability are the result not only of attempts by some [to pass over collective rules for their benefit], but also of the state's attempts to intervene in local affairs which have undermined the power of the traditional assemblies and compromised their ability to enforce the rules of the commons... Governmental interference in the management of the commons, while arresting conflicts, has, in some areas, removed the power and creativity of the traditional Berber forms of governance and frozen the territorial fluidity of the Berber kinship networks that sustained the agdal strategy for centuries" (pp.41-42).

In spite of some localized attempts at a real partnership, the prevailing nature of forester-peasant relationships still 
relies on distributive negotiation with a strong asymmetry in terms of power and competency recognition. In this sense, this situation exemplifies what Ostrom (1990) calls the "social dilemma," and particularly the problem of a minimal recognition of rights to organize by external government authorities, the seventh requirement judged compulsory in order to ensure long-enduring common pool resources management. The first steps towards decentralization of environmental policies in Morocco, by giving enhanced prerogatives to communes, have largely ignored customary institutions that are still the de facto natural resource managers, and, in some cases, have led to conflicts, populism and pressure for their use (Romagny et al. 2008).

The Moroccan Forestry Administration has quite recently explicitly recognized the importance of taking into account local populations' constraints and wishes in order to achieve efficient forest management. Participation and concerted forest management are also emphasized in the National Forest Program, adopted in 1999, which promotes "a new approach which combines strategic planning, and long-term, decentralized and participative processes [which are] necessary to improve the success rate of projects... and to improve livelihood and incomes of rural populations through the rational, sustainable, and participatory management of natural resources" (MCEF 1999). However, the Moroccan forest code remains similar to the original Dahir of 1917 and its coercive vision of forestry. Moroccan forestry administration agents are therefore asked to manage forest areas through a participatory process without being provided with the legal tools to do so, and usually without a minimum of training in rural sociology and mediation.

At present, the only existing tool available to forest administration departments for initiating a participatory process with local populations is a ministerial decree allowing for monetary compensation (about U.S.\$25/Ha, corresponding to the mean monetary value of forage found in Moroccan rangelands) for excluding grazing animals for several years ( 7 to 12 ) from forest areas to be regenerated, on the condition that the farmers organize themselves into a formal association (under the 1958 law). Though it constitutes a first step towards promoting dialogue, and in certain cases could be of great utility, this measure highlights how much still remains to be done, for at least three reasons: first, because it ignores the traditional institutions and imposes another form of organization which can lead locally to conflicts and competition; second, because neither terms of reference nor objectives are negotiable; and third, because technically it is generally incompatible with the activity cycles of peasants who have to find solutions for feeding livestock throughout the year within the framework of their extensive agropastoral systems, traditionally characterized by sequential uses of different areas within the annual cycle. This illustrates that both a changing vision of the role of the State in terms of forest management and competency allocation (Genin and Benchekroun 2007) and a better mutual understanding (whether spelled out or not) concerning the bases of the "action logics" (Amblard et al. 1996) of the different stakeholders involved, appear to be equally necessary in order to promote a properly concerted and effective forest management system.

Forest Agdal, a Possible Basis for Shared Management Objectives?

We argue that the development of participatory actions based on the agdal institution could be a useful instrument to bring together the traditional and foresters' visions of forest management because it fulfils most of the characteristics that can lead to successful outcomes in common pool resource management (Agrawal 2007; Gibson et al. 2005; Ostrom 2005). The main point in balance remains a clear official recognition of traditional institutions' competency in matters of forest management.

Agdal practices and forestry management systems have in common at least three fundamental generic properties: 1) a common main objective, i.e., resource conservation, 2) a shared condition, i.e., a clear identification of users and definition of rules, and, 3) a shared basic form of action, i.e., temporary respite from use. In this sense, they could constitute a sound basis for finding original solutions for better coordination between the stakeholders, and for more efficient environmental governance (Dietz et al. 2003; Paavola 2007). In effect, the main interests of agdal traditional forest management, apart being directly operational in the villages, lie in the integration of protection measures into the agropastoral cycles of the rural population (time compatibility), and in creating a diversity of "resource-spaces" of differentiated functions and of a high degree of usefulness for rural livelihoods (space compatibility). However, agdal traditional forest management falls short of an ideal solution by concentrating pressure, and hence degradation, in nonprotected parts of forest territory, and in poorly taking into account the requirements of a broader approach to the ecological management of biodiversity.

Forest administration services, on their own, are deeply concerned with conservation techniques, and are in touch with developing environmental engineering approaches to resource management. They are also concerned by a global vision for enhancing national environmental policies and ways to achieve them. They need to upgrade their functions towards providing environmental advice and facilitation instead of exclusively focusing their efforts on land management of rural areas. There are ways to introduce changes towards the decentralized status of territories without changing patterns of legal land ownership of 
torests (long-term rent, concession, territory charter, etc.), but they call for a real willingness to delegate natural resource management to representative and functional institutions found locally.

In fact, there is already a certain synergy in agdal management between locals and foresters, particularly in the argan forest region. Firstly, because local people are increasingly considered as institutional partners by forest authorities through local associations and Communal Authorities that have decision-making powers for agdal opening and closing dates. Secondly, because in some parts of the argan region, foresters are considered as customary stakeholders associated with the image of patron saints who were historically the actual mediators of forest management (Simenel 2010). In fact, certain forms of compromise and collaboration take place informally on the basis of agdal management. In some cases, the argan forest is divided into two parts: the foresters' agdal (agdal Iboughaba) and the ancestors' agdal (agdal id $b a b n ' s)$ with differentiated uses rights. Moreover, foresters are sometimes asked to involve themselves in tree management in private fields, and agdal practices tend to extend beyond the state-owned forest towards the overall territory covered by argan trees. These dynamics tend to promote informal co-management and a certain sharing of reponsabilities for the argan forests' future.

More generally, the implementation of territory charters (Genin and Benchekroun 2007) and collective organizations respectful of traditional entities, such as the ethno-linage cooperatives found in pastoral areas of the north-east of the country (Mahdi 2009), could play a role in enforcing the patrimony consciousness and protection of these forested areas. From a technical perspective, joint efforts in the development of sylvopastoral systems with enhanced foraging value of the forest understory would also favour fruitful collaboration between foresters and peasants. Finally, sharing vernacular and scientific knowledge, know-how and ideas concerning tree regeneration management could in our opinion lead to the opening up of new directions towards sustainable uses and development of these important woodlands, due to the richness found on both sides in this field.

\section{Conclusion}

By describing the actual practices of local populations in the management of tree and forest resources, and relating them to their role in rural livelihoods, we have followed a kind of structural functionalist approach (Holmwood 2005; Merton 1957) in the sense that we were interested in describing an organization whose constituent elements can be characterised in terms of their integrated functional roles that explain its overall structure and behaviour
(Pacherie 19y5). Forest areas are not built within a monolithic mould following the technical precepts of the classical forestry approach. In particular, the so-called rural or domestic forests widely found around the world present specific traits, both in terms of physical and physiognomic components, of functions and benefits, and of techniques, rationale and management objectives (Michon et al. 2007). These are shifting traits depending on deep socioeconomic, cultural and environmental dynamics, and on the influences of national and international policies that impact traditional social structures and landscapes. Their related practices are only 'the tip of the iceberg' of the intimate relationships that Berber societies have woven with their environment. Rituals, children's learning processes about their natural environment, local terminology, tree classification and representation systems also provide indices for the acknowledgement that biological diversity is related to cultural diversity in knowledge, languages and practices, and that sustaining both is surely necessary for both ecological and cultural well-being (Gellner 1969; Sullivan 2008; Simenel 2010).

Hence, though declining dramatically in certain areas (see Aubert (2010) for the Middle Atlas for example), the agdal system is still perpetuated in several zones because of its proven efficiency in at least three areas: reinforcing cultural identity and social cohesion (Dominguez et al. 2010), encouraging risk management options, and allowing spatial and temporal complementarity within the territory. In our view, these are key points for strengthening the functioning and enhancing the resilience of traditional rural societies in restrictive environments.

Traditional forest management in Southern Morocco has been demonstrated to have in some respects a positive impact in terms of mitigating biodiversity loss of landscapes and in favouring the perpetuation of high quality ecosystems, such as the unique argan forests. However, this diversity is always related to its functions for satisfying different requirements for local livelihoods. In this sense we propose the notion of the "biodiversity of functions," which could be a useful indicator as a basis for assessing practices and their impact in these typical domestic or rural forests.

Finally, the environmental and socioeconomic role of these rural forests cannot be understood outside the overall functioning of the local agro-pastoral system and the socioterritorial organization of Berber society. Traditional territorial structures and their associated underlying logic inherited from long-term environmental-cultural interactions (Berque 1978; Ilahiane 1999) are too often poorly understood and undervalued by experts and rural development specialists. Notwithstanding, we support the argument that they are very instructive for developing renewed integrated strategies for the sustainable development of the Berber rural and forest management systems. 
Ackmowieugements 1 mis stuay was conuucted as a condouranve project involving the Laboratoire Population-EnvironnementDéveloppement (IRD-Université de Provence, Marseille, France) and the Faculté des Sciences Semlalia (Université Cadi Ayyad, Marrakech, Morocco). We are grateful for their financial support to the Agence Nationale de le Recherche (ANR-06-PADD-014) and to the Institut Français de la Biodiversité (IRD-IFB/INRA n 2886). We appreciate the help of Hubert Mazurek in formatting figures. Special thanks go to anonymous reviewers of Human Ecology for their useful comments, as well as the Editorial Board for his generous effort in improving wording.

\section{References}

Agrawal, A. (2007). Forests, Governance, and Sustainability: Common Property Theory and Its Contributions. International Journal of the Commons 1(1): 111-136.

Alaoui, S., Alifriqui, M., and Simmoneaux, V. (2009). Recent Dynamics of the Wet Pastures at Oukaimeden Plateau (High Atlas Mountains, Morocco). Biodiversity and Conservation 18(1): 167-189.

Amblard, H., Bernoux, P., Herreos, G., and Livian, Y. F. (1996). Les Nouvelles Approches Sociologiques Des Organisations. Editions du Seuil, Paris.

Armitage, D. (2005). Adaptative Capacity and Community-Based Natural Resource Management. Environmental Management 35 (6): 703-715.

Aubert, P. M. (2010). Action publique et societe rurale dans la gestion des forets marocaines: changement social et efficacite environnementale. PhD Thesis, AgroParisTech-ENGREF, Montpellier, France.

Aubert, P. M., Leroy, M., and Auclair, L. (2009). Moroccan Forestry Policies and Local Forestry Management in the High Atlas: A Cross Analysis of Forest Administration and Local Institutions. Small-scale Forestry 8: 175-191.

Auclair, L., and Alifriqui, M. (2007). Les agdals du Haut Atlas Marocain: Enjeux d'une Recherche Pluridisciplinaire. Cahiers de recherche du Centre Jacques Berque, Rabat 3: 60-79.

Ba, M. (2009). Etude des impacts des usages et pratiques des populations sur les conformations de l'arganier, zone d'Amsitten, Province d'Essaouira. Master Dissertation, ENFI, Salé, Morocco

Behnke, H., Scoones, I., and Kerven, C. (1993). Range Ecology at Desequilibrium. ODI, London.

Bencherifa, A., and Johnson, D. L. (1991). Changing Resource Management Strategies and Their Environmental Impacts in the Middle Atlas Mountains of Morocco. Mountain Research and Development 11: 183-194.

Berkes, F. (2008). Sacred Ecology. Traditional Ecological Knowledge and Management Systems, 2nd ed. Routledge, London.

Berkes, F., Colding, J., and Folke, C. (2003). Navigating SocialEcological Systems: Building Resilience for Complexity and Change. Cambridge University Press, Cambridge.

Berque, J. (1978). Structures Sociales Du Haut Atlas. PUF, Paris.

Blaikie, P., Brown, K., Stocking, M., et al. (1997). Knowledge in Action: Local Knowledge as a Development Resource and Barriers to its Incorporation in Natural Resource Research and Development. Agricultural Systems 55: 217-237.

Bloch, M. (1995). Devenir le paysage. La clarté pour les Zafimaniry. In Voisenat, C. (ed.), Paysage au pluriel. Editions de la Maison des Sciences de l'Homme, Paris.

Clements, J. E. (1936). Nature and Structure of the Climax. Journal of Ecology 24: 252-284.

Cordier, J. B. (2007). Impacts écologiques des pratiques d'agdal sur les peuplements forestiers et propositions de gestions alternatives. Master Dissertation FIF-ENGREF, Nancy, France.

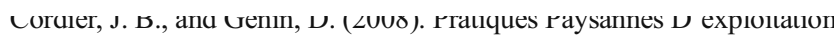
Des Arbres et Paysages Forestiers du Haut Atlas Marocain. Revue Forestière Française 60(5): 571-588.

Couvreur, G. (1968). La vie Pastorale Dans le Haut Atlas Central. Revue de Géographie du Maroc 13: 3-47.

Daget, P., and Poissonet, J. (1972). Une Methode D'analyse Phytologique Des Prairies. Critères D'application. Annales d'Agronomie 22: 5-41.

Davis, D. (2005). Indigenous Knowledge and the Desertification Debate: Problematising Expert Knowledge in North Africa. Geoforum 36: 509-524.

Dietz, T., Ostrom, E., and Stern, P. (2003). The Struggle to Govern the Commons. Science 302: 1907-1912.

Dominguez, P., Zorondo-Rodriguez, F., and Reyes-Garcia, V. (2010). Relationships Between Religious Beliefs and Mountain Pasture Uses: A Case Study in the High Atlas Mountains of Marrakech, Morocco. Human Ecology 38(3): 351-362.

Gauquelin, T., Bertaudière, V., Montès, N., Badri, W., and Asmode, J. F. (1999). Endangered Stands of Thuriferous Juniper in the Western Mediterranean Basin: Ecological Status, Conservation and Management. Biodiversity and Conservation 8: 1476-1498.

Gellner, E. (1969). Saints of the Atlas. Weidenfeld and Nicolson, London.

Genin, D. (2008). The Agdal system or the art of managing spatiotemporality of forage resources and risks in the High Atlas Mountains of Morocco. In Proceeding of the VIII International Rangeland Congress (ed.), Multifunctional Grasslands in a changing world. Vol. 2, Guangdong People's Publishing House, Guangzhou, China.

Genin, D., and Benchekroun, F. (eds.) (2007). De La Parole Aux Gestes... Eléments De Reflexion Sur Les Dispositifs De Gestion Concertée Des Ressources Forestières et Pastorales Au Maroc. Ed. ENFI-Ambassade de France-IRD, Rabat, Morocco.

Genin D., Kerautret L., Hammi S., and Alifriqui M. (2011). Biodiversité et pratiques d'agdal: un élément de l'environnement à l'épreuve de ses fonctions d'utilité pour les sociétés rurales du Haut Atlas. In Auclair, L., and Alifriqui, M. (eds.), Agdal. Patrimoine socio-écologique de l'Atlas marocain. IRCAM Editions, Rabat, Morocco, (in press).

Gibson, C., Williams, J., and Ostrom, E. (2005). Local Enforcement and Better Forests. World Development 33(2): 273-284.

Hammi, S., Simonneaux, V., Cordier, J. B., Genin, D., Alifriqui, M., Montès, N., and Auclair, L. (2010). Can Traditional Management Buffer Forest Depletion? Evolution of the Moroccan High Atlas Mountains' Forest Using Remote Sensing and Vegetation Analysis. Forest Ecology and Management 260: 1861-1872.

Holmwood, J. (2005). Functionalism and its critics. In Harrington, A. (ed.), Modern Social Theory, an Introduction. Oxford University Press, Oxford.

Ilahiane, H. (1999). The Berber agdal Institution: Indigenous Range Management in the Atlas Mountains. Ethnology 38(1): 21-45.

Joffre, R., Rambal, S., and Ratte, J. P. (1999). The Dehesa System of Southern Spain and Portugal as a Natural Ecosystem Mimic. Agrofrestry Systems 45: 57-79.

Leach, M., Mearns, R., and Scoones, I. (1999). Environment Entitlements: Dynamics and Institutions in Community-Based Natural Resource Management. World Development 27: 225-247.

Lecestre-Rollier, B. (1986). Anthropologie d'un espace montagnard: les Ayt Bou Guemez du Haut Atlas marocain. PhD Thesis, Univ. René Descartes, Paris V, France.

Mahdi, M. (1999). Pasteur de 1'Atlas: Production Pastorale, Droit et Rituel. Fondation Conrad Adenauer, Casablanca.

Mahdi, M. (2009). La Tribu au Secours du Développement Pastoral. Etudes Rurales 184: 133-148. 


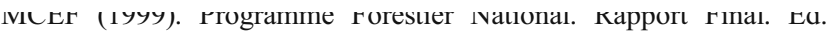
Ministère Chargé des Eaux et Forêts, Rabat, Morocco.

Merton, R. (1957). Social Theory and Social Structure, Revised and Enlarged. The Free Press of Glencoe, London.

Michon, G., De Foresta, H., Levang, P., and Verdeaux, F. (2007). Domestic Forests: A New Paradigm for Integrating Local Communities' Forestry Into Tropical Forest Science. Ecology and Society 12(2). http://www.ecologyandsociety.org/vol12/iss2/art1/

M'Hirit, O., Benzyane, M., Benchekroun, F., El Yousfi, S. M., and Bendaanoun, M. (2002). L'arganier, Une Espèce Fruitière-Forestière a Usages Multiples. Mardaga, Sprimont, Belgica.

Olivier de Sardan, J. P. (2000). Rendre compte du point de vue des acteurs: principes méthodologiques de l'enquête de terrain en sciences sociales. In Lavigne, D. P., Sellama, N. E., and Mathieu, M. (eds.), Les enquêtes participatives en débat. Karthala, Paris.

Ostrom, E. (1990). Governing the Commons: the evolution of institutions for collective action. Cambridge Univ. Press, Cambridge.

Ostrom, E. (2005). Understanding Institutional Diversity. Princeton University Press, Princeton.

Paavola, J. (2007). Institutions and Environmental Governance: A Reconceptualization. Ecological Economics 63: 93-103.

Pacherie, E. (1995). Le fonctionnalisme: état des lieux. Intellectica 21: 9-37.

Parlee, B., Berkes, F., and Teetl'it Gwich'in Renewable Resource Council (2006). Indigenous knowledge of ecological variability anu Commons mandagement: a case stuay ur veny narvesing from Northern Canada. Human Ecology 34: 515-528.

Peloquin, C., and Berkes, F. (2009). Local knowledge, subsistence harvests, and social-ecological complexity in James Bay. Human Ecology 37: 533-545.

Romagny, B., Auclair, L., and Elgueroua, A. (2008). La gestion des ressources naturelles dans la vallée des Aït Bouguemez (Haut Atlas): la montagne marocaine à la recherche d'innovations institutionnelles. Mondes en développement 63(1): 63-80.

Simenel, R. (2010). L'origine est aux frontières. Ed. CNRS/MSH, Coll. Les chemins de l'ethnologie, Paris, France.

Simenel, R. (2011). Des saints ou des pierres pour construire une forêt? Une ethnoécologie historique des forêts d'arganiers du Sud Marocain. Techniques et Culture 56 (in press).

Simenel, R., Michon, G., Auclair, L., Romagny, B., Thomas, Y., and Guyon, M. (2009). L'argan: 1'huile Qui Cache La Forêt Domestique. De La Valorisation Du Produite à La Naturalisation De L'écosystème. Autrepart 50: 51-73.

Sullivan, S. (2008). Bioculturalism, Shamanism and Economics. Resurgence 250: article 2631.

Uprety, L. (2002). Role of Institutions and Organizations for the Sustainable Management of Forest and Pasture as Common Property Resources in Nepal: An Overview of the Indigenous and Traditional Practices. Dhaulagiri Journal of Sociology 2: 31-64. 